\title{
Review Article \\ Environmental Ligands of the Aryl Hydrocarbon Receptor and Their Effects in Models of Adult Liver Progenitor Cells
}

\author{
Jan Vondráček ${ }^{1}$ and Miroslav Machala ${ }^{2}$ \\ ${ }^{1}$ Department of Cytokinetics, Institute of Biophysics of the Czech Academy of Sciences, 61265 Brno, Czech Republic \\ ${ }^{2}$ Department of Chemistry and Toxicology, Veterinary Research Institute, 62100 Brno, Czech Republic \\ Correspondence should be addressed to Jan Vondráček; vondracek@ibp.cz
}

Received 28 January 2016; Accepted 7 April 2016

Academic Editor: Kameshwar P. Singh

Copyright (C) 2016 J. Vondráček and M. Machala. This is an open access article distributed under the Creative Commons Attribution License, which permits unrestricted use, distribution, and reproduction in any medium, provided the original work is properly cited.

\begin{abstract}
The toxicity of environmental and dietary ligands of the aryl hydrocarbon receptor (AhR) in mature liver parenchymal cells is well appreciated, while considerably less attention has been paid to their impact on cell populations exhibiting phenotypic features of liver progenitor cells. Here, we discuss the results suggesting that the consequences of the AhR activation in the cellular models derived from bipotent liver progenitors could markedly differ from those in hepatocytes. In contact-inhibited liver progenitor cells, the AhR agonists induce a range of effects potentially linked with tumor promotion. They can stimulate cell cycle progression/proliferation and deregulate cell-to-cell communication, which is associated with downregulation of proteins forming gap junctions, adherens junctions, and desmosomes (such as connexin 43, E-cadherin, $\beta$-catenin, and plakoglobin), as well as with reduced cell adhesion and inhibition of intercellular communication. At the same time, toxic AhR ligands may affect the activity of the signaling pathways contributing to regulation of liver progenitor cell activation and/or differentiation, such as downregulation of Wnt/ $\beta$-catenin and TGF- $\beta$ signaling, or upregulation of transcriptional targets of YAP/TAZ, the effectors of Hippo signaling pathway. These data illustrate the need to better understand the potential role of liver progenitors in the AhRmediated liver carcinogenesis and tumor promotion.
\end{abstract}

\section{Introduction}

The liver, a central organ responsible for maintaining the homeostasis in organism, plays an essential role in metabolism, both synthesizing a number of important molecules and metabolizing nutrients, xenobiotics, or various endogenous substrates [1]. It is primarily involved in glycogen storage, drug detoxification, bile production and secretion, as well as in production of serum proteins, and so forth. The metabolic and synthetic functions of the liver are performed primarily by hepatocytes, which make approximately $80 \%$ of the total liver mass [1]. Disruption of the liver capacity to detoxify, failure to secrete bile, or aberrant synthesis of plasma proteins leads to development of liver diseases, such as cirrhosis, which may ultimately result in the liver failure [2].

The liver is also an organ with a remarkable regeneration capacity that is capable of recovering both mass and function after an injury. Although hepatocytes have a very low turnover rate and under normal conditions almost all of them are quiescent cells (which reside in $G_{0}$ phase of cell cycle), following liver injury, they reenter cell cycle in order to allow restoration of the original cell mass [2,3]. Hepatocyte proliferation represents a major mechanism responsible for the liver regeneration and homeostasis [4], and, under normal conditions, the liver regeneration is thought to be primarily mediated by self-duplication of mature hepatocytes (and biliary epithelial cells) $[2,5,6]$. Nevertheless, during strong hepatocyte depletion or when hepatocyte proliferation is inhibited, the population of liver progenitor cells may serve as a second line of defense against liver injury/failure $[5,7]$. The adult liver progenitor cells can give rise both to hepatocytes and to biliary epithelial cells $[8,9]$, although their origin, as well as their exact contribution to liver regeneration, is a matter of an ongoing debate (for recent reviews, see [2, 5-7]).

Given the importance of the liver in detoxification of xenobiotics, it is not surprising that liver cells also constitute a major target for a number of toxicants and/or their reactive 
intermediates. The toxic ligands of the aryl hydrocarbon receptor (AhR), such as 2,3,7,8-tetrachlorodibenzo-p-dioxin (TCDD) and related dioxin-like compounds (DLCs), are well-known liver toxicants, which induce multiple forms of liver damage and contribute to hepatocarcinogenesis [10]. A brief description of the AhR functions and mechanisms of the AhR-dependent signaling is also provided as a part of this review. A significant majority of currently available studies evaluating the mechanisms underlying the toxicity of the AhR agonists in the liver have so far focused on hepatocytes as a principal target of DLCs. Therefore, the primary goal of this review is to provide an overview of experimental studies evaluating the impact of toxic AhR ligands on cellular models either derived from liver progenitor cells or exhibiting phenotypic features of liver progenitors.

\section{Adult Liver Progenitor Cells}

The progenitor cells in adult liver have been considered to represent cells that may enable the liver to regenerate upon severe or chronic injury linked with impairment of proliferative capacity of hepatocytes [8]. The activation/accumulation of cells exhibiting progenitor or mixed hepatobiliary phenotypes has been observed in a number of human liver disease conditions, including submassive liver necrosis and chronic viral hepatitis, or during both alcoholic and nonalcoholic fatty liver disease $[11,12]$. These cells have been proposed to represent the human equivalent of rodent oval cells (facultative liver stem cells), which are activated during a number of experimental conditions blocking the restoration of the liver mass by hepatocytes $[8,13]$. The activation of oval cells in experimental animals has been documented to occur in response to a wide range of toxic insults to the liver, including (i) application of toxins/carcinogens (such as 2acetylaminofluorene and ethionine) in combination with partial hepatectomy; (ii) use of diets containing carbon tetrachloride or 5-diethoxycarbonyl-1,4-dihydrocollidine (DDC), or (iii) using experimental choline-deficient diet supplemented with ethionine (CDE) [14-17]. These treatments lead to emergence of oval cells with bipotential ability to differentiate into both hepatocytes and biliary epithelial cells $[18,19]$.

The origin of rodent oval cells is still not fully clear; however, they have been hypothesized to originate from the cells that are located within canals of Hering [20]. This structure, located between hepatocytes and biliary epithelial cells, may serve as a niche for these bipotential progenitor cells; however, as will be discussed later, other origins of liver progenitor cells have also been proposed, including hepatocytes [21, 22], hepatic stellate cells [23, 24], or cholangiocytes [5]. Oval cells express markers of both the hepatocyte and bile duct lineages, including $\alpha$-fetoprotein (AFP), deltalike 1 homolog (Dlk1), cytokeratin 19 (CK19), SRY- (sex determining region Y-) box 9 (Sox9), epithelial cell adhesion molecule (EpCAM), CD133, or MIC1-1C3 antigen [7, 8, 25]. The expression of these markers seems to be both speciesand injury type-specific [25]. Therefore, additional markers of oval cells are being sought in order to improve both identification and quantification of liver progenitor cells.
The studies evaluating transdifferentiation between hepatic cell types have recently reported a number of controversial findings [2, 5-7]. Transplanted liver progenitor cells may contribute significantly to restoration of liver parenchyma, regenerating both hepatocytes and biliary epithelium [26], and the rodent liver cells expressing various markers of liver progenitors can be successfully induced to give rise to hepatocytes and/or biliary epithelial cells [27-30]. The adult bile duct derived Lgr5-positive progenitor cells have been derived and expanded from human liver, which can then be differentiated into functional hepatocytes in vitro or in vivo [31]. However, the exact contribution of adult liver progenitor cells to liver regeneration upon liver injury in vivo remains controversial, especially when considering the results of recent studies using genetic lineage tracing experiments. Whereas one of the first such studies has indicated that cells of biliary origin could be a major source of hepatocytes [32], others have, on the contrary, reported that adult liver progenitor cells provide only a minor fraction of cells contributing to liver regeneration, which is primarily mediated by hepatocytes under normal conditions $[4,33,34]$. Several recent studies have argued that hepatocytes arise from preexisting hepatocytes during liver regeneration or that hepatocytes within injured liver are a source of bipotential adult liver progenitors, which then contribute to restoration of hepatocyte mass through transdifferentiation $[22,35,36]$. Two recent studies have also indicated that specific progenitor/stemlike cell populations may exist in the adult liver. Recently, a preexisting population of hybrid periportal hepatocytes, expressing low levels of biliary markers, has been proposed to possess a high regenerative capacity and to contribute to restoration of liver mass after chronic hepatocyte-depleting injuries [37]. Another study has identified a population of proliferating and self-renewing Axin2-positive cells located close to the central vein within a niche established by the Wnt (wingless/integrated-1) producing endothelial cells. This population of stem cells, which is present in uninjured steady state liver, has been proposed to contribute to homeostatic liver cell renewal, similar to other organs [38].

Thus, a number of controversies currently surround both the identification of adult liver progenitor cells and their potential role(s) in homeostatic liver, during liver regeneration or in hepatocarcinogenesis. A recent study has suggested that ductular reactions may not give rise to hepatocellular carcinoma (HCC) [39], while others have proposed that dysregulated self-renewal of liver progenitor cells serves as an early event in hepatocarcinogenesis [40]. Nevertheless, regardless of the above issues concerning their origin or their role in liver regeneration, adult liver progenitor cells (which possess a significant self-renewal capacity) appear to give rise to certain types of liver cancer [41]. A significant percentage of HCC cases simultaneously exhibits both hepatocytic and biliary features [42]. A notable example is the combined hepatocholangiocarcinomas, an aggressive and heterogeneous group of liver tumors exhibiting intermediate features between hepatocytes and cholangiocytes, which have been suggested to arise from liver stem/progenitor cells [43]. This indicates that some liver cancer subtypes contain cells with phenotypic and/or functional features of liver progenitor 
cells, possibly originating from adult liver progenitor cell populations. Therefore, these cell populations might also constitute an important target for liver carcinogens, including the toxic environmental AhR ligands.

\section{Toxic Ligands of the AhR and Their Hepatotoxic and Carcinogenic Effects}

The AhR is a ligand-activated transcription factor, a member of the bHLH/PAS (basic helix-loop-helix/Per-Arnt-Sim) family of transcriptional regulators [44], which regulates the expression and activity of a number of genes participating in the regulation of liver cell function or hepatocarcinogenesis [10]. The AhR is in inactive state localized within the cytosolic protein complex containing chaperone protein hsp90 (heat shock protein 90), cochaperon $\mathrm{p} 23$, and immunophilin XAP2 (ARA9; AIP) protein. Following the binding of its cognate ligands, the AhR translocates to the nucleus and forms a dimer with the AhR nuclear translocator (Arnt). This dimer recognizes so-called xenobiotic/dioxin response elements (XRE/DRE) located within the regulatory regions of various AhR target genes. These include phase I xenobiotic metabolizing enzymes, such as cytochrome P450 family 1 (CYP1) enzymes and several phase II conjugation enzymes [45]. However, the AhR also regulates a number of genes contributing to the regulation of cell proliferation, differentiation, senescence, or programmed cell death [46-50]. This suggests that the AhR could play a major role in cell fate decisions; therefore, the aberrant long-term activation of the AhR by persistent toxic AhR ligands may contribute to important biological processes involved in hepatocarcinogenesis [51].

The AhR-null mice exhibit a number of liver defects, including reduced liver size, smaller hepatocytes, development of mild to severe liver fibrosis, accumulation of lipids, inflammation, or remodeling of the liver vascular architecture [52-54]. In some AhR knockout mice models, mild oval cells hyperplasia has been observed [52]. The liganddependent activation of AhR mediates toxicity of a variety of environmental pollutants, including polychlorinated dibenzo-p-dioxins, dibenzofurans, and biphenyls (PCBs), or polycyclic aromatic hydrocarbons (PAHs) [44]. The exposure to TCDD leads to tumor promotion, teratogenic effects, epithelial hyperplasia, thymic involution, porphyria, and (at high doses) a severe wasting syndrome followed by death of experimental animals [55]. In the rodent liver, TCDD induces a range of effects leading to hepatocellular hypertrophy, bile duct hyperplasia, formation of multinucleate hepatocytes (in some rodents), steatosis and inflammatory cell infiltration, transient liver swelling, and, at the cellular level, plasma membrane abnormalities and proliferation of endoplasmic reticulum [56]. Most of the acute toxic effects of TCDD in rodent liver are mediated by activation of the AhR in hepatocytes [54].

The AhR activation is the major and common mode of action of DLCs [10]. This allowed establishing the "toxic equivalency factor" (TEF) approach for risk assessment of mixtures containing DLCs, which is based on the concept of determination of the potencies of DLCs to activate various
AhR-dependent endpoints allowing establishment of consensus TEF values (relative to TCDD) for individual DLCs [57]. Dose-additive carcinogenicity of mixtures of DLCs has been experimentally confirmed and it supports the use of the TEF approach [58].

Importantly, apart from their acute toxicity, persistent AhR ligands have been shown to act as powerful liver tumor promoters and this effect is AhR-dependent $[59,60]$. TCDD and other dioxin-like compounds, such as 2,3,4,7,8pentachlorodibenzofuran or $3,3^{\prime}, 4,4^{\prime}, 5$-pentachlorobiphenyl (PCB 126), have been listed by the International Agency for Research on Cancer as carcinogenic to humans (group 1 human carcinogens) [61]. These compounds have been shown to induce multiple cancer types in experimental animals $[10,62]$. The chronic toxicity and carcinogenicity of both TCDD and PCB 126 have been evaluated in two-year bioassays in female rats $[63,64]$. Increased incidence of nonneoplastic liver lesions (including hepatocyte hypertrophy, altered hepatocellular foci, inflammation, oval cell and bile duct hyperplasia, cholangiofibrosis, and nodular hyperplasia) and increased incidences of hepatocellular adenomas and cholangiocarcinomas were found after exposure to DLCs. Importantly, some of these lesions also contained a prominent component of biliary epithelium and/or oval cells [65]. This suggests that liver progenitor cells might contribute to development of cancer in experimental animals exposed to DLCs.

During recent years, the AhR has been also implicated in regulation of physiological functions of stem cells of various tissue origins, in particular in hematopoietic stem cells [6672], or in cancer stem cells [73, 74]. Importantly, a recent study has suggested that the AhR activation can have a major impact on expansion of rodent hepatic stem cells while simultaneously reducing the viability of hepatoblasts [75]. Thus, DLCs may apparently differentially affect liver cells at less differentiated stages (including adult liver progenitor cells), and their impact on liver progenitors could markedly differ from their effects in mature hepatocytes. In this review, we summarize the results of experimental studies indicating that the AhR activation may alter various functions of adult liver progenitor cells, which include deregulation of cell cycle progression/proliferation and cell-to-cell communication, as well as modulation of activities of signaling pathways regulating liver progenitor cell activation and/or differentiation.

\section{The Role of AhR in Regulation of Cell Cycle and Proliferation in Cellular Models Derived from Hepatocytes}

The mechanisms underlying the role of the AhR in carcinogenesis have recently been reviewed by several authors and it has been proposed that the AhR can play both oncogenic and tumor suppressive roles in various cancer types, in a tissue-dependent manner [76-78]. In the liver, the AhR appears to function as tumor suppressor gene in the absence of its toxic ligands [79], whereas its aberrant long-term activation induces liver carcinogenesis [10]. This is supported also by the observation that the constitutively 
active AhR mutant promotes carcinogenesis in mouse liver [80]. A number of mechanisms have been suggested to contribute to carcinogenic effects of DLCs in the liver, including altered proliferation of preneoplastic cells or inhibition of apoptosis leading to clonal expansion of altered hepatic foci $[10,47]$. Disruption of cell proliferation control and loss of responsiveness to growth suppression belong among the hallmarks of cancer [81], which have been also suggested to contribute to carcinogenic effects of environmental chemicals [82].

The presence or absence of the AhR in cells may significantly modulate their proliferative behavior [83]. In rodent hepatoma cell models, TCDD treatment leads to AhRdependent inhibition of $G_{0} / G_{1}$ to S-phase progression and accumulation of cells in $G_{0} / G_{1}$ phase of cell cycle [84]. This effect has been suggested to be mediated via various mechanisms including induction of the cyclin-dependent kinase inhibitor $\mathrm{p} 27^{\mathrm{Kip} 1}$ [85], inhibition of E2F1-dependent gene expression, which is mediated by interactions between the AhR and retinoblastoma protein [86-88], displacement of E2F from the E2F-responsive promoters, or additional mechanisms dependent on AhR transcriptional partner, Arnt $[89,90]$. TCDD and related compounds block cell cycle progression and cell proliferation in a majority of liver cell models used in toxicology [91, 92]. TCDD also suppresses liver regeneration following partial hepatectomy via the induction of $\mathrm{p} 21^{\mathrm{Cip} 1 / \text { Waf } 1}$ activity, which is mediated by the AhR acting together with the tumor suppressor Kruppel-like factor 6, which functions as a noncanonical AhR binding partner $[93,94]$. Contrary to these observations, TCDD pretreatment increases proliferative response of hepatocytes to hepatomitogen 1,4-bis[2-(3,5-dichloropyridyloxy)] benzene (TCPOBOP) in regenerating liver, which suggests that the role of the AhR in cell cycle regulation of liver cells could be more complex than simply inhibiting cell cycle progression into S-phase [95].

\section{The Impact of AhR Agonists on Cell Cycle and Proliferation in Models of Adult Liver Progenitor Cells}

Unlike in hepatocytes or hepatoma cells, various types of AhR ligands have been found to promote proliferation of rat liver progenitor cells in vitro. The WB-F344 cell line, isolated from the liver of adult male F344 rat, exhibits phenotypic properties of rat oval cells [96]. Upon transplantation into the liver of syngeneic rats, these cells differentiate into hepatocytes and they retain the capacity to differentiate into both biliary and hepatic lineages [97]. When WB-F344 cells are cultivated at high cell densities, under conditions of contact inhibition of cell proliferation, TCDD stimulates their proliferation $[98,99]$. The contact inhibition of cell proliferation is a tightly regulated process, which restricts the cell division of confluent nontransformed cells [81]. Since tumor promotion is characterized by unbalanced proliferation either due to increased proliferation or due to decreased level of apoptosis, it has been proposed that the loss of contact inhibition is a toxic event, which may contribute to liver tumor promotion
[48]. The proliferative effect of TCDD in contact-inhibited rat liver progenitor cells can be replicated also with other classes of the AhR ligands, including PCBs, polycyclic aromatic hydrocarbons, flavonoids, or endogenous AhR ligands [100103]. The mechanism responsible for this induction of cell proliferation is strictly AhR-dependent; however, it does not depend on presence of Arnt, a transcriptional partner of the AhR $[104,105]$. The proliferative effects of TCDD or other DLCs are not limited to this model of rat liver progenitor cells; similar observations have been made using some other epithelial cell models $[48,105]$. In contrast, recently, the AhR activation has been found to block cell cycle progression in isolated mouse oval cells [106]. Interestingly, we have recently observed that TCDD stimulates cell proliferation in undifferentiated human liver HepaRG cells [107]. These cells, isolated from adult human liver [108], show phenotypical features of undifferentiated bipotent liver cells when cultured at low densities, and they are capable of in vitro differentiation towards both hepatocyte-like and biliary-like cells [109]. Together, the present data seem to indicate that, in undifferentiated liver cells exhibiting progenitor or mixed hepatobiliary phenotypes, toxic AhR ligands can induce cell proliferation, while simultaneously suppressing proliferation of hepatocytes or hepatocyte-like cells.

In the contact-inhibited rat liver progenitor cells, activation of the AhR leads to induction of JunD expression, followed by induction of cyclin A, which in turn leads to an increased activity of cyclin A/cyclin-dependent kinase 2 complex, which drives cell proliferation [105]. The disruption of contact inhibition in this liver progenitor cell model has been found to be linked also with alterations of cell-tocell communication and modulation of signaling pathways involved both in liver regeneration and in hepatocarcinogenesis [48, 98, 107, 110-112]. TCDD has been observed to stimulate membrane translocation of c-Src kinase in WBF344 cells [98]. This nonreceptor tyrosine kinase has been proposed to form a part of the cytoplasmic AhR complex and it significantly modulates cell behavior, including stimulation of migration and invasion of tumor cells [113-115].

Induction of cell proliferation in contact-inhibited WBF344 cells is also associated with decreased levels of connexin 43, a major protein forming gap junctions in epithelial cells, which corresponds with reduction of gap junction plaques at cell membranes and inhibition of gap junctional intercellular communication [110]. The AhR activation in rat liver progenitor cells reduces the expression of plakoglobin ( $\gamma$-catenin), an important constituent of desmosomes and adherens junctions; this type of regulation of plakoglobin by the AhR has been confirmed also in other cell types [112, 116]. Finally, disruption of contact inhibition in WB-F344 cells also leads to downregulation of E-cadherin (and $\beta$-catenin) and reduced cell adhesion, suggesting that an impaired adherens junction function could be one of the consequences of the AhR-mediated disruption of cell proliferation control [111]. All of these findings are in line with the proposed role of the AhR as a regulator of cell adhesion and cell-to-cell communication $[48,49]$, two key mechanisms establishing and maintaining the contact inhibition of cell proliferation $[48,117,118]$. Nevertheless, it should be stated that the in vivo 
relevance of these findings remains open and future studies should establish the importance of the AhR-dependent disruption of contact inhibition in the carcinogenic effects of its toxic ligands.

\section{The Signaling Pathways Regulating Proliferation, Differentiation, and Fate of Adult Liver Progenitor Cells and Their Potential Interactions with the AhR Signaling}

The analysis of global gene expression in WB-F344 cells released from the contact inhibition (by persistent toxic AhR ligand, PCB 126) has revealed a significant deregulation of a number of signaling components and transcriptional targets of the signaling pathways that are known to contribute to regulation of liver progenitor cell activation and/or differentiation [119]. An outline of the effects of toxic AhR ligands in this model of rat liver progenitor cell model is provided in Figure 1.

The major affected pathways included downregulation of $\mathrm{Wnt} / \beta$-catenin and transforming growth factor- $\beta$ (TGF- $\beta$ ) signaling pathways, upregulation of ligands of the epidermal growth factor receptor (EGFR), or induction of some genes regulated by transcriptional cofactor Yes-associated protein (YAP) and/or its paralogue, transcriptional coactivator with PDZ-binding motif (TAZ; also known as WWTR1), the effectors of Hippo signaling pathway.

Notably, the global gene expression data suggested that multiple members of Wnt signaling pathway can be deregulated by toxic AhR ligands in liver progenitor cells [119]. $\mathrm{Wnt} / \beta$-catenin signaling pathway is a key pathway regulating both development and adult tissue homeostasis. In the absence of Wnt stimulation, $\beta$-catenin binds to cytoplasmic destruction complex, which is formed by tumor suppressor proteins Axin and adenomatous polyposis coli, and kinases belonging to glycogen synthase kinase 3 and casein kinase 1 families. Within this complex, $\beta$-catenin is phosphorylated, ubiquitinated, and consequently degraded via a proteasome [120-122]. The activation of cognate Wnt receptor (Frizzled) and coreceptor (low density lipoprotein 5/6) by Wnts or related ligands inactivates the cytoplasmic destruction complex, thus leading to accumulation and nuclear translocation of $\beta$-catenin. The nuclear $\beta$-catenin forms complexes with LEF (lymphoid enhancer-binding factor)/TCF (T-cell factor) transcription factors and drives transcription of their target genes in a cell context-specific manner [120-122]. Apart from its signaling role, $\beta$-catenin plays also an important structural role in formation of adherens junctions, main epithelial adhesive junctions further contributing to the regulation of $\beta$-catenin activity and turnover [123]. In the liver, Wnt $/ \beta$ catenin signaling plays a major role in its embryonic development, early postnatal growth, regeneration, and maintenance of adult liver functions, such as liver zonation (for recent reviews, see $[124,125])$. Deregulation of Wnt signaling is also an important factor in liver carcinogenesis [125]. Importantly, a number of reports have indicated that the activity of this pathway controls proliferation and/or differentiation of liver progenitor cells, as well as liver cancer stem cells [40, 126-131].

It is becoming increasingly evident that $\mathrm{Wnt} / \beta$-catenin signaling interacts with the AhR at multiple levels [132]. The increased activity of $\beta$-catenin upregulates the AhR expression in various tissues, including mouse liver $[133,134]$. Given that $\beta$-catenin activity is high within the pericentral zone $[135,136]$, this may imply that the cells surrounding the central vein (including the proposed liver stem cells contributing to hepatocyte renewal [38]) could be more sensitive to toxic AhR ligands, because of significantly higher AhR levels in this region, as compared with periportal zone [137]. $\beta$-Catenin plays a major role in the expression of xenobiotic metabolizing enzymes in the liver $[133,136]$. These include in particular the CYP1 family enzymes regulated by the AhR, which are involved in bioactivation of numerous environmental carcinogens [45, 138-141]. In rat liver progenitor cells, activation of Wnt/ $\beta$-catenin has been found to significantly promote expression of both Cyplal and Cyplb1 [111] playing a principal role in bioactivation and genotoxicity of the environmental AhR ligands, such as PAHs [45].

Importantly, at the same time, TCDD could block the $\beta$ catenin-dependent signaling in liver progenitor cells. WBF344 cells are sensitive to the activation of the canonical Wnt signaling by recombinant Wnt ligands, which induce a moderate cell proliferation in this cell model [101, 142]. The activation of AhR by TCDD significantly decreases levels of the active form of $\beta$-catenin (dephosphorylated on S37 and T41 residues) in liver progenitor cells [111]. Downregulation of $\beta$-catenin by activated AhR has also been observed in other cell models [143]. Additionally, TCDD induces dephosphorylation of Dvl (dishevelled) 2 and Dvl3 proteins that play a key role as the branching points regulating both canonical and noncanonical Wnt pathways [144]. In line with this, the sustained AhR activation has been found to reduce expression of a number of $\mathrm{Wnt} / \beta$-catenin pathway targets in WB-F344 cells [111, 119].

The AhR-mediated deregulation of Wnt $/ \beta$-catenin-dependent transcription in WB-F344 has been also linked with changes in their progenitor phenotype since CK14 and CK19, which are abundantly expressed in oval cells $[145,146]$, are downregulated by TCDD, while CK8 is simultaneously upregulated, which suggests that progenitor cells exposed to the AhR ligands may progress towards more hepatocyte-like phenotype [111]. This is supported also by the observation that expression of other genes associated with hepatic progenitor cell compartment, such as Kitl and Ncaml, is downregulated in WB-F344 cells exposed to toxic AhR ligands [111, 119]. The inhibitory role of the AhR in this important signaling pathway, contributing to regulation of progenitor cell proliferation and phenotype, is also supported by additional studies indicating that $\mathrm{AhR}$ ligands repress production of canonical Wnt ligands and/or repress Wnt/ $\beta$-catenin signaling in a variety of tissues and cell models, including embryonic stem cells $[143,147-151]$. Together, these results indicate that, apart from modulating the structural role of $\beta$-catenin in adherens junctions, toxic AhR ligands might also block its signaling role in liver progenitors. 


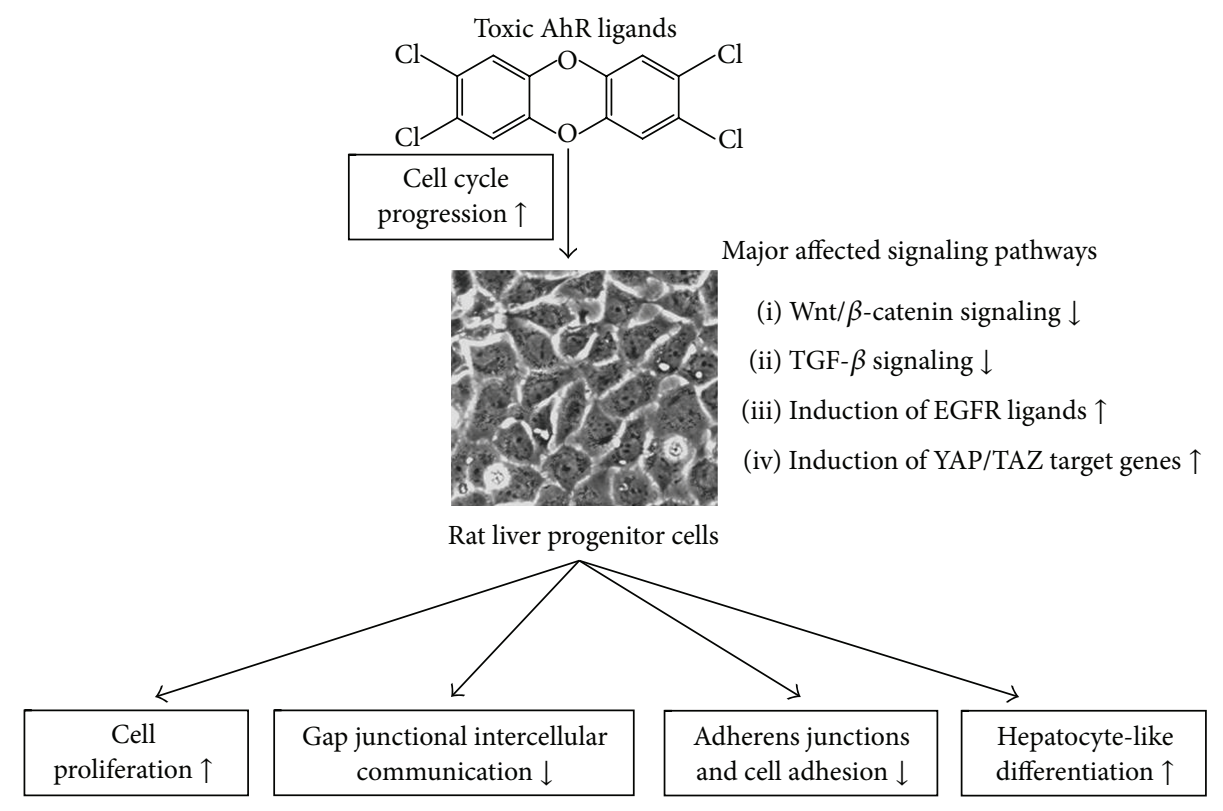

FIGURE 1: A summary of effects of AhR agonists on deregulation of signaling pathways and liver progenitor cell functions in WB-F344 cell model.

Wnt $/ \beta$-catenin signaling is closely connected with the TGF- $\beta$ signaling pathway, since both pathways cross-talk at multiple levels, such as through reciprocal regulation of their ligands or via direct interaction of their signaling effectors within cell nuclei that are involved in transcriptional regulation of common gene targets $[152,153]$. The TGF- $\beta$ family of cytokines includes, apart from TGF- $\beta 1$, a number of proteins playing important roles in embryonic development, adult tissue homeostasis, and the cancer development, such as bone morphogenic proteins and activins/inhibins. TGF$\beta 1$ is a pleiotropic cytokine inducing a range of effects within liver cells, including regulation of cell migration, invasion, and stemness [154]. TGF- $\beta 1$ blocks proliferation and induces apoptosis in mature hepatocytes, while its role in liver progenitor cells is less clear $[154,155]$. Some studies have indicated that adult liver progenitor cells could be less sensitive to the TGF- $\beta 1$-induced apoptosis and its antiproliferative effects than hepatocytes [156-158]. On the other hand, TGF- $\beta 1$ blocks proliferation and promotes apoptosis in oval cell lines derived from DDC-treated mice [17]. Active TGF- $\beta 1$ and $\beta 3$ proteins are elevated in AhR knockout mice, and this corresponds with increased numbers of hepatocytes undergoing apoptosis, as compared with wild-type mice [159]. Interestingly, the analysis of global gene expression changes in WB-F344 cells revealed that AhR ligands could induce expression of follistatin in rat liver progenitors [119]. Upregulation of follistatin by TCDD has been observed also in additional cell models $[160,161]$. This protein directly binds and inhibits activin A, TGF- $\beta$ family member and regulator of the liver homeostasis. Activin A blocks hepatocyte proliferation and induces their apoptosis, while its inhibition via follistatin promotes proliferation and decreases apoptosis in the liver [162]. Since activin A has been shown to induce growth arrest in hepatic progenitor cells [163], its inhibition via the AhR-dependent induction of follistatin might further promote the proliferative effects of toxic AhR ligands in rat liver progenitors. Additionally, AhR ligands have been also observed to downregulate activin receptors, which may pronounce their impact on activin signaling [119].

Growth factor signaling plays an important role in regulation of oval cells response, as it contributes to regulation of their growth, survival, motility, and differentiation $[154,155]$. Rat liver progenitor WB-F344 cells are sensitive both to hepatocyte growth factor (HGF) and to epidermal growth factor (EGF), which both stimulate their proliferation and/or protect them from apoptosis [100, 164]. EGFR can be activated, apart from EGF, also by other functionally related ligands, such as TGF- $\alpha$, heparin-binding EGF (HB-EGF), amphiregulin (Areg), and epiregulin. The EGFR ligands are upregulated during oval cell activation and they promote oval cell expansion in vivo $[165,166]$. Oval cell lines have been also proposed to regulate EGFR signaling also via autocrine mechanism(s) [154]. The treatment of WB-F344 cells with toxic AhR ligands has been found to upregulate several EGFR ligands, including Areg and HB-EGF, in the AhRdependent manner [119]. Areg is a candidate AhR-responsive gene, which has been found to be induced by AhR ligands (or their mixtures) in the developing ureter in vivo, as well as in mouse hepatoma and human oral epithelial cells in vitro $[167,168]$. Whether expression of Areg is increased in response to TCDD in adult liver progenitor cells also in vivo remains to be determined. HB-EGF is another EGFR ligand, which has been shown to contribute to liver regeneration or hepatocarcinogenesis [169-171]. TCDD has been shown to regulate also expression of additional EGFR ligands, such as epiregulin or transforming growth factor- $\alpha[172,173]$; however, these have not been found to be upregulated in WB-F344 cells [119]. Taken together, rat liver progenitor cells 
are capable of the AhR agonist-inducible production of some EGFR ligands; however, the functional role of induction of these growth factors upon AhR activation is not fully clear.

The Hippo signaling pathway is essential for a proper organ size control, tissue regeneration, and stem cell selfrenewal and it can play a significant role in cancer development [174]. In mammals, this pathway consists of a core set of kinases, mammalian Ste2-like kinases 1/2 (Mst1/2), and large tumor suppressor kinases 1/2 (Lats1/2), which control the activity of YAP and TAZ [175]. The establishment of cellcell contacts leads to activation of Hippo kinases, Mst1/2 and Lats1/2, which then inhibit YAP and/or TAZ activity via their cytoplasmic retention and/or proteasomal degradation [175]. In contrast, activation of cell proliferation is linked with active YAP and/or TAZ being present within the nucleus, where they control the expression of a number of growth-promoting or antiapoptotic genes, including connective tissue growth factor (CTGF), cysteine-rich angiogenic inducer 61 (CYR61), or survivin $[176,177]$. The activity of proteins constituting Hippo pathways overlaps at numerous points with other pathways controlling the activation of adult liver progenitor cells, such as Wnt/ $\beta$-catenin signaling [178], and it is a principal regulator of contact inhibition $[177,179]$. In the liver, knockout of Hippo pathway components regulating YAP/TAZ activity or overexpression of YAP leads to disruption of liver size control or development of HCC [180]. The Hippo pathway has been also proposed to contribute to bile duct development and to hepatocyte reprogramming to biliary epithelial cells $[181,182]$. Toxic compounds such as TCBOPOP have been shown to simultaneously increase liver size and increase YAP levels in liver [183]. Both YAP and TAZ have been shown to modulate plasticity and differentiation of hepatocytes, to control development of cancer stem cells during HCC, or to modulate proliferation of HCC cells, thus indicating a potentially important role for Hippo pathway in hepatocarcinogenesis [181, 184-186].

At present, the information on interactions between the AhR activation and Hippo signaling is very limited. Interestingly, the disruption of contact inhibition in rat liver WBF344 cells has been found to be associated with induction of some YAP/TAZ transcriptional targets [107, 119]. Survivin, which is regulated by YAP/TAZ [187], has been found to be upregulated by TCDD in undifferentiated human liver HepaRG cells, simultaneously with disruption of cell cycle control and induction of cell proliferation [107]. These results seem to indicate that activation of proliferative signaling in cellular models of liver progenitors could be linked with YAP/TAZ-dependent activation of some target genes of this pathway; however, at present, the in vivo relevance of these findings remains unclear. Nevertheless, it is of interest that both TCDD and PCB 126 induce expression of CTGF, another YAP/TAZ transcriptional target, in contact-inhibited rat liver progenitor cells $[107,119]$. This protein has been shown to promote hepatocyte-like differentiation of rat liver progenitor cells in vitro [188]; this seems to support the observation that AhR ligands reduce expression of progenitor cell markers and increase levels of hepatocyte-like markers in rat liver progenitors [111]. Nevertheless, TCDD has been also found to repress CTGF mRNA in HL1-1 adult human liver stem-like cell line, while simultaneously inducing YAP mRNA in the same cell model [189], thus suggesting that the role of the AhR in regulation of CTGF could be more complex and perhaps cell-specific.

Inflammatory cytokines have been proposed to play a major role in mediating both the hepatotoxicity of TCDD and the TCDD-induced liver tumor promotion [59, 190]. The production of inflammatory cytokines, such as tumor necrosis factor- $\alpha$ (TNF- $\alpha$ ), also contributes to the expansion of oval cells during experimental rodent liver injury [191], since TNF- $\alpha$ is upregulated during oval cell proliferation, which is induced by CDE diet, and elimination of TNF receptor 1 blocks oval cell response in mice [192]. Interestingly, TNF- $\alpha$ has been found to be a major factor supporting the proliferative effects of DLCs in rat liver oval cells, promoting both cyclin A induction and cell cycle progression in WBF344 cells [193]. This cytokine potentiates the effects of both strong and weak environmental $\mathrm{AhR}$ agonists in rat liver progenitor cells [193, 194]. Moreover, activation of inflammatory signaling by this cytokine, namely, the p38 mitogen-activated kinase activity, further supports inhibition of gap junctional intercellular communication [194], as well as metabolic activation of genotoxic AhR ligands via upregulation of CYP1B1 $[195,196]$. Together, these data seem to support the scenario, where induction of inflammation by toxic AhR ligands in the liver might further support their procarcinogenic effects (deregulation of cell proliferation, induction of DNA damage) in liver progenitors.

\section{Conclusions}

Toxic AhR ligands have been found to disrupt various functions of liver progenitor cell models in vitro, including deregulation of cell proliferation control and cell-to-cell communication, or to alter the activity of signaling pathways relevant for the maintenance of liver homeostasis, activation of oval cell response, or liver carcinogenesis. These include modulations of Wnt $/ \beta$-catenin and TGF- $\beta$ pathways and induction of expression of EGF-related growth factors or transcriptional targets of Hippo pathway, which are involved in both regenerative and oncogenic signaling. The available data seem to indicate that, apart from their other wellrecognized hepatotoxic effects, the environmental ligands of the AhR may alter the functions of cell populations exhibiting phenotypic features of adult liver progenitor cells (or undifferentiated liver cells), with potential to serve as precursors of hepatocytes and biliary epithelial cells. These results may have implications for the carcinogenic effects of sustained AhR activation in the liver; however, it should be noted that a major limitation of the available data is currently their reliance on the use of in vitro models of liver progenitor cells. Future studies should therefore focus on analyzing the impact of the AhR activation on liver progenitors in vivo, in order to ascertain the relevance of these findings for experimental chemical carcinogenesis, which may help us to better understand the liver toxicity and carcinogenicity of the AhR ligands, both in the experimental animals and in humans. 


\section{Competing Interests}

The authors declare that they have no competing interests.

\section{Authors' Contributions}

Jan Vondráček and Miroslav Machala revised the literature and wrote the paper.

\section{Acknowledgments}

The authors acknowledge the grant support of the Czech Science Foundation (Grant no. 13-07711S to Jan Vondráček and P503/12/G147 to Miroslav Machala).

\section{References}

[1] J. W. Grisham, "Organization principles of the liver," in The Liver: Biology and Pathobiology, I. Arias, A. Wolkoff, J. Boyer et al., Eds., pp. 3-15, Wiley-Blackwell, Hoboken, NJ, USA, 2009.

[2] B. Z. Stanger, "Cellular homeostasis and repair in the mammalian liver," Annual Review of Physiology, vol. 77, pp. 179-200, 2015.

[3] G. K. Michalopoulos and M. C. DeFrances, "Liver regeneration," Science, vol. 276, no. 5309, pp. 60-65, 1997.

[4] Y. Malato, S. Naqvi, N. Schürmann et al., "Fate tracing of mature hepatocytes in mouse liver homeostasis and regeneration," The Journal of Clinical Investigation, vol. 121, no. 12, pp. 4850-4860, 2011.

[5] G. K. Michalopoulos and Z. Khan, "Liver stem cells: experimental findings and implications for human liver disease," Gastroenterology, vol. 149, no. 4, pp. 876-882, 2015.

[6] A. Miyajima, M. Tanaka, and T. Itoh, "Stem/progenitor cells in liver development, homeostasis, regeneration, and reprogramming," Cell Stem Cell, vol. 14, no. 5, pp. 561-574, 2014.

[7] K. J. Riehle, Y. Y. Dan, J. S. Campbell, and N. Fausto, "New concepts in liver regeneration," Journal of Gastroenterology and Hepatology, vol. 26, supplement 1, pp. 203-212, 2011.

[8] N. Fausto, "Liver regeneration and repair: hepatocytes, progenitor cells, and stem cells," Hepatology, vol. 39, no. 6, pp. 1477-1487, 2004.

[9] S. S. Thorgeirsson and J. W. Grisham, "Overview of recent experimental studies on liver stem cells," Seminars in Liver Disease, vol. 23, no. 4, pp. 303-312, 2003.

[10] R. A. Budinsky, D. Schrenk, T. Simon et al., "Mode of action and dose-response framework analysis for receptor-mediated toxicity: the aryl hydrocarbon receptor as a case study," Critical Reviews in Toxicology, vol. 44, no. 1, pp. 83-119, 2014.

[11] T. A. Roskams, L. Libbrecht, and V. J. Desmet, "Progenitor cells in diseased human liver," Seminars in Liver Disease, vol. 23, no. 4, pp. 385-396, 2003.

[12] E. Turányi, K. Dezsö, J. Csomor, Z. Schaff, S. Paku, and P. Nagy, "Immunohistochemical classification of ductular reactions in human liver," Histopathology, vol. 57, no. 4, pp. 607-614, 2010.

[13] M. R. Alison, "Characterization of the differentiation capacity of rat-derived hepatic stem cells," Seminars in Liver Disease, vol. 23, no. 4, pp. 325-336, 2003.

[14] B. Akhurst, E. J. Croager, C. A. Farley-Roche et al., "A modified choline-deficient, ethionine-supplemented diet protocol effectively induces oval cells in mouse liver," Hepatology, vol. 34, no. 3, pp. 519-522, 2001.
[15] E. Farber, "Similarities in the sequence of early histological changes induced in the liver of the rat by ethionine, 2-acetylamino-fluorene, and 3 '-methyl-4-dimethylaminoazobenzene," Cancer Research, vol. 16, pp. 142-148, 1956.

[16] E. H. Leduc and J. W. Wilson, "Injury to liver cells in carbon tetrachloride poisoning; histochemical changes induced by carbon tetrachloride in mouse liver protected by sulfaguanidine," AMA Archives of Pathology, vol. 65, no. 2, pp. 147-157, 1958.

[17] K.-H. Preisegger, V. M. Factor, A. Fuchsbichler, C. Stumptner, H. Denk, and S. S. Thorgeirsson, "Atypical ductular proliferation and its inhibition by transforming growth factor betal in the 3,5-diethoxycarbonyl-1,4-dihydrocollidine mouse model for chronic alcoholic liver disease," Laboratory Investigation, vol. 79, no. 2, pp. 103-109, 1999.

[18] H. A. Dunsford, C. Karnasuta, J. M. Hunt, and S. Sell, “Different lineages of chemically induced hepatocellular carcinoma in rats defined by monoclonal antibodies," Cancer Research, vol. 49, no. 17, pp. 4894-4900, 1989.

[19] C. A. Lázaro, J. A. Rhim, Y. Yamada, and N. Fausto, "Generation of hepatocytes from oval cell precursors in culture," Cancer Research, vol. 58, no. 23, pp. 5514-5522, 1998.

[20] S. Paku, J. Schnur, P. Nagy, and S. S. Thorgeirsson, "Origin and structural evolution of the early proliferating oval cells in rat liver," The American Journal of Pathology, vol. 158, no. 4, pp. 1313-1323, 2001.

[21] K. Yanger, Y. Zong, L. R. Maggs et al., "Robust cellular reprogramming occurs spontaneously during liver regeneration," Genes \& Development, vol. 27, no. 7, pp. 719-724, 2013.

[22] B. D. Tarlow, C. Pelz, W. E. Naugler et al., "Bipotential adult liver progenitors are derived from chronically injured mature hepatocytes," Cell Stem Cell, vol. 15, no. 5, pp. 605-618, 2014.

[23] C. Kordes, I. Sawitza, S. Götze, D. Herebian, and D. Häussinger, "Hepatic stellate cells contribute to progenitor cells and liver regeneration," The Journal of Clinical Investigation, vol. 124, no. 12, pp. 5503-5515, 2014.

[24] G. A. Michelotti, G. Xie, M. Swiderska et al., "Smoothened is a master regulator of adult liver repair," The Journal of Clinical Investigation, vol. 123, no. 6, pp. 2380-2394, 2013.

[25] T. Itoh and A. Miyajima, "Liver regeneration by stem/progenitor cells," Hepatology, vol. 59, no. 4, pp. 1617-1626, 2014.

[26] W.-Y. Lu, T. G. Bird, L. Boulter et al., "Hepatic progenitor cells of biliary origin with liver repopulation capacity," Nature Cell Biology, vol. 17, pp. 971-983, 2015.

[27] C. Dorrell, L. Erker, J. Schug et al., "Prospective isolation of a bipotential clonogenic liver progenitor cell in adult mice," Genes \& Development, vol. 25, no. 11, pp. 1193-1203, 2011.

[28] M. Huch, C. Dorrell, S. F. Boj et al., "In vitro expansion of single $\mathrm{Lgr}^{+}$liver stem cells induced by Wnt-driven regeneration," Nature, vol. 494, no. 7436, pp. 247-250, 2013.

[29] M. Okabe, Y. Tsukahara, M. Tanaka et al., "Potential hepatic stem cells reside in $\mathrm{EpCAM}^{+}$cells of normal and injured mouse liver," Development, vol. 136, no. 11, pp. 1951-1960, 2009.

[30] S. Shin, G. Walton, R. Aoki et al., "Foxl1-Cre-marked adult hepatic progenitors have clonogenic and bilineage differentiation potential," Genes and Development, vol. 25, no. 11, pp. 1185-1192, 2011.

[31] M. Huch, H. Gehart, R. Van Boxtel et al., "Long-term culture of genome-stable bipotent stem cells from adult human liver," Cell, vol. 160, no. 1-2, pp. 299-312, 2015.

[32] K. Furuyama, Y. Kawaguchi, H. Akiyama et al., "Continuous cell supply from a Sox9-expressing progenitor zone in adult liver, 
exocrine pancreas and intestine," Nature Genetics, vol. 43, no. 1, pp. 34-41, 2011.

[33] D. Rodrigo-Torres, S. Affò, M. Coll et al., "The biliary epithelium gives rise to liver progenitor cells," Hepatology, vol. 60, no. 4, pp. 1367-1377, 2014.

[34] R. Español-Suñer, R. Carpentier, N. Van Hul et al., "Liver progenitor cells yield functional hepatocytes in response to chronic liver injury in mice," Gastroenterology, vol. 143, no. 6, pp. 1564-1575.e7, 2012.

[35] J. R. Schaub, Y. Malato, C. Gormond, and H. Willenbring, "Evidence against a stem cell origin of new hepatocytes in a common mouse model of chronic liver injury," Cell Reports, vol. 8, no. 4, pp. 933-939, 2014.

[36] K. Yanger, D. Knigin, Y. Zong et al., "Adult hepatocytes are generated by self-duplication rather than stem cell differentiation," Cell Stem Cell, vol. 15, no. 3, pp. 340-349, 2014.

[37] J. Font-Burgada, S. Shalapour, S. Ramaswamy et al., "Hybrid periportal hepatocytes regenerate the injured liver without giving rise to cancer," Cell, vol. 162, no. 4, pp. 766-779, 2015.

[38] B. Wang, L. Zhao, M. Fish, C. Y. Logan, and R. Nusse, "Selfrenewing diploid Axin $2^{+}$cells fuel homeostatic renewal of the liver," Nature, vol. 524, no. 7564, pp. 180-185, 2015.

[39] S. Jörs, P. Jeliazkova, M. Ringelhan et al., "Lineage fate of ductular reactions in liver injury and carcinogenesis," The Journal of Clinical Investigation, vol. 125, no. 6, pp. 2445-2457, 2015.

[40] T. Chiba, Y.-W. Zheng, K. Kita et al., "Enhanced self-renewal capability in hepatic stem/progenitor cells drives cancer initiation," Gastroenterology, vol. 133, no. 3, pp. 937-950, 2007.

[41] T. Roskams, "Liver stem cells and their implication in hepatocellular and cholangiocarcinoma," Oncogene, vol. 25, no. 27, pp. 3818-3822, 2006.

[42] R. C. Lo and I. O. Ng, "Hepatic progenitor cells: their role and functional significance in the new classification of primary liver cancers," Liver Cancer, vol. 2, no. 2, pp. 84-92, 2013.

[43] C. Coulouarn, C. Cavard, L. Rubbia-Brandt et al., "Combined hepatocellular-cholangiocarcinomas exhibit progenitor features and activation of Wnt and TGF $\beta$ signaling pathways," Carcinogenesis, vol. 33, no. 9, pp. 1791-1796, 2012.

[44] B. E. McIntosh, J. B. Hogenesch, and C. A. Bradfield, "Mammalian Per-Arnt-Sim proteins in environmental adaptation," Annual Review of Physiology, vol. 72, pp. 625-645, 2009.

[45] D. W. Nebert and T. P. Dalton, "The role of cytochrome P450 enzymes in endogenous signalling pathways and environmental carcinogenesis," Nature Reviews Cancer, vol. 6, no. 12, pp. 947960, 2006.

[46] R. Barouki, X. Coumoul, and P. M. Fernandez-Salguero, "The aryl hydrocarbon receptor, more than a xenobiotic-interacting protein," FEBS Letters, vol. 581, no. 19, pp. 3608-3615, 2007.

[47] K. W. Bock and C. Köhle, "Ah receptor- and TCDD-mediated liver tumor promotion: clonal selection and expansion of cells evading growth arrest and apoptosis," Biochemical Pharmacology, vol. 69, no. 10, pp. 1403-1408, 2005.

[48] C. Dietrich and B. Kaina, "The aryl hydrocarbon receptor (AhR) in the regulation of cell-cell contact and tumor growth," Carcinogenesis, vol. 31, no. 8, pp. 1319-1328, 2010.

[49] T. Kung, K. A. Murphy, and L. A. White, “The aryl hydrocarbon receptor (AhR) pathway as a regulatory pathway for cell adhesion and matrix metabolism," Biochemical Pharmacology, vol. 77, no. 4, pp. 536-546, 2009.
[50] A. Puga, C. Ma, and J. L. Marlowe, “The aryl hydrocarbon receptor cross-talks with multiple signal transduction pathways," Biochemical Pharmacology, vol. 77, no. 4, pp. 713-722, 2009.

[51] K. A. Mitchell and C. J. Elferink, "Timing is everything: consequences of transient and sustained AhR activity;" Biochemical Pharmacology, vol. 77, no. 6, pp. 947-956, 2009.

[52] P. Fernandez-Salguero, T. Pineau, D. M. Hilbert et al., "Immune system impairment and hepatic fibrosis in mice lacking the dioxin-binding Ah receptor," Science, vol. 268, no. 5211, pp. 722726, 1995.

[53] J. V. Schmidt, G. H.-T. Su, J. K. Reddy, M. C. Simon, and C. A. Bradfield, "Characterization of a murine Ahr null allele: involvement of the Ah receptor in hepatic growth and development," Proceedings of the National Academy of Sciences of the United States of America, vol. 93, no. 13, pp. 6731-6736, 1996.

[54] J. A. Walisser, E. Glover, K. Pande, A. L. Liss, and C. A. Bradfield, "Aryl hydrocarbon receptor-dependent liver development and hepatotoxicity are mediated by different cell types," Proceedings of the National Academy of Sciences of the United States of America, vol. 102, no. 49, pp. 17858-17863, 2005.

[55] A. Poland and J. C. Knutson, "2,3,7,8-Tetrachlorodibenzo-pdioxin and related halogenated aromatic hydrocarbons: examination of the mechanism of toxicity," Annual Review of Pharmacology and Toxicology, vol. 22, pp. 517-554, 1982.

[56] R. Pohjanvirta and J. Tuomisto, "Short-term toxicity of 2,3,7,8tetrachlorodibenzo-p-dioxin in laboratory animals: effects, mechanisms, and animal models," Pharmacological Reviews, vol. 46, no. 4, pp. 483-549, 1994.

[57] M. Van den Berg, L. Birnbaum, A. T. C. Bosveld et al., "Toxic equivalency factors (TEFs) for PCBs, PCDDs, PCDFs for humans and wildlife," Environmental Health Perspectives, vol. 106, no. 12, pp. 775-792, 1998.

[58] N. J. Walker, P. W. Crockett, A. Nyska et al., "Dose-additive carcinogenicity of a defined mixture of 'dioxin-like compounds", Environmental Health Perspectives, vol. 113, no. 1, pp. 43-48, 2005.

[59] G. D. Kennedy, M. Nukaya, S. M. Moran et al., "Liver tumor promotion by 2,3,7,8-tetrachlorodibenzo-p-dioxin is dependent on the aryl hydrocarbon receptor and TNF/IL-1 receptors," Toxicological Sciences, vol. 140, no. 1, pp. 135-143, 2014.

[60] H. C. Pitot, T. Goldsworthy, H. A. Campbell, and A. Poland, "Quantitative evaluation of the promotion by 2,3,7,8tetrachlorodibenzo-p-dioxin of hepatocarcinogenesis from diethylnitrosamine," Cancer Research, vol. 40, no. 10, pp. 3616-3620, 1980.

[61] IARC, Chemical Agents and Related Occupations-A Review of Human Carcinogens, IARC, Lyon, France, 2012.

[62] S. Knerr and D. Schrenk, "Carcinogenicity of 2,3,7,8-tetrachlorodibenzo-p-dioxin in experimental models," Molecular Nutrition and Food Research, vol. 50, no. 10, pp. 897-907, 2006.

[63] National Toxicology Program, "NTP technical report on the toxicology and carcinogenesis studies of 2,3,7,8-tetrachlorodibenzo-p-dioxin (TCDD) (CAS No. 1746-01-6) in female Harlan Sprague-Dawley rats (Gavage Studies)," National Toxicology Program Technical Report Series, no. 521, pp. 4-232, 2006.

[64] National Toxicology Program, "Toxicology and carcinogenesis studies of a binary mixture of 3,3,4,4,5-pentachlorobiphenyl (PCB 126) (Cas No. 57465-28-8) and 2,3',4,4'5-pentachlorobiphenyl (PCB 118) (Cas No. 31508-00-6) in female Harlan Sprague-Dawley rats (gavage studies)," National Toxicology Program Technical Report Series, vol. 531, pp. 1-218, 2006. 
[65] J. R. Hailey, N. J. Walker, D. M. Sells, A. E. Brix, M. P. Jokinen, and A. Nyska, "Classification of proliferative hepatocellular lesions in Harlan Sprague-Dawley rats chronically exposed to dioxin-like compounds," Toxicologic Pathology, vol. 33, no. 1, pp. 165-174, 2005.

[66] J. A. Bennett, K. P. Singh, Z. Unnisa, S. L. Welle, and T. A. Gasiewicz, "Deficiency in aryl hydrocarbon receptor (AHR) expression throughout aging alters gene expression profiles in murine long-term hematopoietic stem cells," PLoS ONE, vol. 10, no. 7, Article ID e0133791, 2015.

[67] A. E. Boitano, J. Wang, R. Romeo et al., "Aryl hydrocarbon receptor antagonists promote the expansion of human hematopoietic stem cells," Science, vol. 329, no. 5997, pp. 13451348, 2010.

[68] R. P. Bunaciu and A. Yen, "Activation of the aryl hydrocarbon receptor AhR Promotes retinoic acid-induced differentiation of myeloblastic leukemia cells by restricting expression of the stem cell transcription factor Oct4," Cancer Research, vol. 71, no. 6, pp. 2371-2380, 2011.

[69] F. L. Casado, K. P. Singh, and T. A. Gasiewicz, "Aryl hydrocarbon receptor activation in hematopoietic stem/progenitor cells alters cell function and pathway-specific gene modulation reflecting changes in cellular trafficking and migration," Molecular Pharmacology, vol. 80, no. 4, pp. 673-682, 2011.

[70] M. W. Roeven, S. Thordardottir, A. Kohela et al., "The aryl hydrocarbon receptor antagonist stemregeninl improves in vitro generation of highly functional natural killer cells from $\mathrm{CD} 34^{+}$hematopoietic stem and progenitor cells," Stem Cells and Development, vol. 24, no. 24, pp. 2886-2898, 2015.

[71] K. P. Singh, R. W. Garrett, F. L. Casado, and T. A. Gasiewicz, "Aryl hydrocarbon receptor-null allele mice have hematopoietic stem/progenitor cells with abnormal characteristics and functions," Stem Cells and Development, vol. 20, no. 5, pp. 769-784, 2011.

[72] T. Xu, Y. Zhou, L. Qiu et al., "Aryl hydrocarbon receptor protects lungs from cockroach allergen-induced inflammation by modulating mesenchymal stem cells," The Journal of Immunology, vol. 195, no. 12, pp. 5539-5550, 2015.

[73] M. Contador-Troca, A. Alvarez-Barrientos, J. M. Merino et al., "Dioxin receptor regulates aldehyde dehydrogenase to block melanoma tumorigenesis and metastasis," Molecular Cancer, vol. 14, no. 1, article 148, 2015.

[74] G. J. Prud'Homme, Y. Glinka, A. Toulina, O. Ace, V. Subramaniam, and S. Jothy, "Breast cancer stem-like cells are inhibited by a non-toxic aryl hydrocarbon receptor agonist," PLoS ONE, vol. 5, no. 11, Article ID e13831, 2010.

[75] J. A. Harrill, B. B. Parks, E. Wauthier, J. C. Rowlands, L. M. Reid, and R. S. Thomas, "Lineage-dependent effects of aryl hydrocarbon receptor agonists contribute to liver tumorigenesis," Hepatology, vol. 61, no. 2, pp. 548-560, 2015.

[76] S. Feng, Z. Cao, and X. Wang, "Role of aryl hydrocarbon receptor in cancer," Biochimica et Biophysica Acta-Reviews on Cancer, vol. 1836, no. 2, pp. 197-210, 2013.

[77] I. A. Murray, A. D. Patterson, and G. H. Perdew, "Aryl hydrocarbon receptor ligands in cancer: friend and foe," Nature Reviews Cancer, vol. 14, no. 12, pp. 801-814, 2014.

[78] S. Safe, S.-O. Lee, and U.-H. Jin, "Role of the aryl hydrocarbon receptor in carcinogenesis and potential as a drug target," Toxicological Sciences, vol. 135, no. 1, pp. 1-16, 2013.

[79] Y. Fan, G. P. Boivin, E. S. Knudsen, D. W. Nebert, Y. Xia, and A. Puga, "The aryl hydrocarbon receptor functions as a tumor suppressor of liver carcinogenesis," Cancer Research, vol. 70, no. 1, pp. 212-220, 2010.

[80] O. Moennikes, S. Loeppen, A. Buchmann et al., "A constitutively active dioxin/aryl hydrocarbon receptor promotes hepatocarcinogenesis in mice," Cancer Research, vol. 64, no. 14, pp. 47074710, 2004.

[81] D. Hanahan and R. A. Weinberg, "Hallmarks of cancer: the next generation," Cell, vol. 144, no. 5, pp. 646-674, 2011.

[82] R. Nahta, F. Al-Mulla, R. Al-Temaimi et al., "Mechanisms of environmental chemicals that enable the cancer hallmark of evasion of growth suppression," Carcinogenesis, vol. 36, supplement 1, pp. S2-S18, 2015.

[83] Q. Ma and J. P. Whitlock Jr., "The aromatic hydrocarbon receptor modulates the Hepa 1clc7 cell cycle and differentiated state independently of dioxin," Molecular and Cellular Biology, vol. 16, no. 5, pp. 2144-2150, 1996.

[84] C. Weiss, S. K. Kolluri, F. Kiefer, and M. Göttlicher, "Complementation of Ah receptor deficiency in hepatoma cells: negative feedback regulation and cell cycle control by the Ah receptor," Experimental Cell Research, vol. 226, no. 1, pp. 154-163, 1996.

[85] S. K. Kolluri, C. Weiss, A. Koff, and M. Göttlicher, "p27(Kip1) induction and inhibition of proliferation by the intracellular Ah receptor in developing thymus and hepatoma cells," Genes and Development, vol. 13, no. 13, pp. 1742-1753, 1999.

[86] C. J. Elferink, N.-L. Ge, and A. Levine, "Maximal aryl hydrocarbon receptor activity depends on an interaction with the retinoblastoma protein," Molecular Pharmacology, vol. 59, no. 4, pp. 664-673, 2001.

[87] N.-L. Ge and C. J. Elferink, "A direct interaction between the aryl hydrocarbon receptor and retinoblastoma protein: linking dioxin signaling to the cell cycle," Journal of Biological Chemistry, vol. 273, no. 35, pp. 22708-22713, 1998.

[88] A. Puga, S. J. Barnes, T. P. Dalton, C.-Y. Chang, E. S. Knudsen, and M. A. Maier, "Aromatic hydrocarbon receptor interaction with the retinoblastoma protein potentiates repression of E2Fdependent transcription and cell cycle arrest," The Journal of Biological Chemistry, vol. 275, no. 4, pp. 2943-2950, 2000.

[89] G. Huang and C. J. Elferink, "Multiple mechanisms are involved in Ah receptor-mediated cell cycle arrest," Molecular Pharmacology, vol. 67, no. 1, pp. 88-96, 2005.

[90] J. L. Marlowe, E. S. Knudsen, S. Schwemberger, and A. Puga, "The aryl hydrocarbon receptor displaces p300 from E2Fdependent promoters and represses $S$ phase-specific gene expression," The Journal of Biological Chemistry, vol. 279, no. 28, pp. 29013-29022, 2004.

[91] C. J. Elferink, "Aryl hydrocarbon receptor-mediated cell cycle control," Progress in Cell Cycle Research, vol. 5, pp. 261-267, 2003.

[92] A. Puga, Y. Xia, and C. Elferink, "Role of the aryl hydrocarbon receptor in cell cycle regulation," Chemico-Biological Interactions, vol. 141, no. 1-2, pp. 117-130, 2002.

[93] D. P. Jackson, H. Li, K. A. Mitchell, A. D. Joshi, and C. J. Elferink, "Ah receptor-mediated suppression of liver regeneration through NC-XRE-driven p21Cip1 expression," Molecular Pharmacology, vol. 85, no. 4, pp. 533-541, 2014.

[94] K. A. Mitchell, C. A. Lockhart, G. Huang, and C. J. Elferink, "Sustained aryl hydrocarbon receptor activity attenuates liver regeneration," Molecular Pharmacology, vol. 70, no. 1, pp. 163170, 2006.

[95] K. A. Mitchell, S. R. Wilson, and C. J. Elferink, "The activated aryl hydrocarbon receptor synergizes mitogen-induced murine liver hyperplasia," Toxicology, vol. 276, no. 2, pp. 103-109, 2010. 
[96] M.-S. Tsao, J. D. Smith, K. G. Nelson, and J. W. Grisham, "A diploid epithelial cell line from normal adult rat liver with phenotypic properties of 'oval' cells," Experimental Cell Research, vol. 154, no. 1, pp. 38-52, 1984.

[97] D. A. Shafritz and M. D. Dabeva, "Liver stem cells and model systems for liver repopulation," Journal of Hepatology, vol. 36, no. 4, pp. 552-564, 2002.

[98] C. Köhle, H. Gschaidmeier, D. Lauth, S. Topell, H. Zitzer, and K. W. Bock, "2,3,7,8-Tetrachlorodibenzo-p-dioxin (TCDD)mediated membrane translocation of $\mathrm{c}$-Src protein kinase in liver WB-F344 cells," Archives of Toxicology, vol. 73, no. 3, pp. 152-158, 1999.

[99] C. Dietrich, D. Faust, S. Budt et al., “2,3,7,8-Tetrachlorodibenzop-dioxin-dependent release from contact inhibition in WBF344 cells: involvement of cyclin A," Toxicology and Applied Pharmacology, vol. 183, no. 2, pp. 117-126, 2002.

[100] K. Chramostová, J. Vondráček, L. Šindlerová, B. Vojtěěek, A. Kozubík, and M. Machala, "Polycyclic aromatic hydrocarbons modulate cell proliferation in rat hepatic epithelial stem-like WB-F344 cells," Toxicology and Applied Pharmacology, vol. 196, no. 1, pp. 136-148, 2004.

[101] J. Procházková, A. Kozubík, M. Machala, and J. Vondráček, "Differential effects of indirubin and 2,3,7,8tetrachlorodibenzo-p-dioxin on the aryl hydrocarbon receptor (AhR) signalling in liver progenitor cells," Toxicology, vol. 279, no. 1-3, pp. 146-154, 2011.

[102] J. Vondráček, M. Machala, V. Bryja et al., "Aryl hydrocarbon receptor-activating polychlorinated biphenyls and their hydroxylated metabolites induce cell proliferation in contactinhibited rat liver epithelial cells," Toxicological Sciences, vol. 83, no. 1, pp. 53-63, 2005.

[103] J. Zatloukalová, L. Švihálková-Šindlerová, A. Kozubík, P. Krčmář, M. Machala, and J. Vondráček, " $\beta$-naphthoflavone and 3/-methoxy-4/-nitroflavone exert ambiguous effects on Ah receptor-dependent cell proliferation and gene expression in rat liver 'stem-like' cells," Biochemical Pharmacology, vol. 73, no. 10, pp. 1622-1634, 2007.

[104] Z. Andrysík, J. Vondráček, M. Machala et al., “The aryl hydrocarbon receptor-dependent deregulation of cell cycle control induced by polycyclic aromatic hydrocarbons in rat liver epithelial cells," Mutation Research-Fundamental and Molecular Mechanisms of Mutagenesis, vol. 615, no. 1-2, pp. 8797, 2007.

[105] C. Weiss, D. Faust, I. Schreck et al., “TCDD deregulates contact inhibition in rat liver oval cells via Ah receptor, JunD and cyclin A," Oncogene, vol. 27, no. 15, pp. 2198-2207, 2008.

[106] D. Faust, S. Kletting, E. Ueberham, and C. Dietrich, "Aryl hydrocarbon receptor-dependent cell cycle arrest in isolated mouse oval cells," Toxicology Letters, vol. 223, no. 1, pp. 73-80, 2013.

[107] J. Svobodová, M. Kabátková, L. Šmerdová et al., “The aryl hydrocarbon receptor-dependent disruption of contact inhibition in rat liver WB-F344 epithelial cells is linked with induction of survivin, but not with inhibition of apoptosis," Toxicology, vol. 333, pp. 37-44, 2015.

[108] P. Gripon, S. Rumin, S. Urban et al., "Infection of a human hepatoma cell line by hepatitis B virus," Proceedings of the National Academy of Sciences of the United States of America, vol. 99, no. 24, pp. 15655-15660, 2002.

[109] V. Cerec, D. Glaise, D. Garnier et al., "Transdifferentiation of hepatocyte-like cells from the human hepatoma HepaRG cell line through bipotent progenitor," Hepatology, vol. 45, no. 4, pp. 957-967, 2007.

[110] Z. Andrysík, J. Procházková, M. Kabátková et al., "Aryl hydrocarbon receptor-mediated disruption of contact inhibition is associated with connexin 43 downregulation and inhibition of gap junctional intercellular communication," Archives of Toxicology, vol. 87, no. 3, pp. 491-503, 2013.

[111] J. Procházková, M. Kabátková, V. Bryja et al., “The interplay of the aryl hydrocarbon receptor and $\beta$-catenin alters both AhRdependent transcription and wnt $\beta$-catenin signaling in liver progenitors," Toxicological Sciences, vol. 122, no. 2, pp. 349-360, 2011.

[112] J. Procházková, M. Kabátková, L. Ŝmerdová et al., “Aryl hydrocarbon receptor negatively regulates expression of the plakoglobin gene (Jup)," Toxicological Sciences, vol. 134, no. 2, pp. 258-270, 2013.

[113] B. Dong, W. Cheng, W. Li et al., "FRET analysis of protein tyrosine kinase c-Src activation mediated via aryl hydrocarbon receptor," Biochimica et Biophysica Acta-General Subjects, vol. 1810, no. 4, pp. 427-431, 2011.

[114] J. Rey-Barroso, G. P. Colo, A. Alvarez-Barrientos et al., “The dioxin receptor controls $\beta 1$ integrin activation in fibroblasts through a Cbp-Csk-Src pathway," Cellular Signalling, vol. 25, no. 4, pp. 848-859, 2013.

[115] C. Tomkiewicz, L. Herry, L.-C. Bui et al., "The aryl hydrocarbon receptor regulates focal adhesion sites through a non-genomic FAK/Src pathway," Oncogene, vol. 32, no. 14, pp. 1811-1820, 2013.

[116] C. Dietrich, D. Faust, M. Moskwa, A. Kunz, K.-W. Bock, and F. Oesch, "TCDD-dependent downregulation of $\gamma$-catenin in rat liver epithelial cells (WB-F344)," International Journal of Cancer, vol. 103, no. 4, pp. 435-439, 2003.

[117] B. M. Gumbiner and N.-G. Kim, "The Hippo-YAP signaling pathway and contact inhibition of growth," Journal of Cell Science, vol. 127, no. 4, pp. 709-717, 2014.

[118] A. I. McClatchey and A. S. Yap, "Contact inhibition (of proliferation) redux," Current Opinion in Cell Biology, vol. 24, no. 5, pp. 685-694, 2012.

[119] D. Faust, J. Vondráček, P. Krčmář et al., "AhR-mediated changes in global gene expression in rat liver progenitor cells," Archives of Toxicology, vol. 87, no. 4, pp. 681-698, 2013.

[120] J. N. Anastas and R. T. Moon, "WNT signalling pathways as therapeutic targets in cancer," Nature Reviews Cancer, vol. 13, no. 1, pp. 11-26, 2013.

[121] H. Clevers and R. Nusse, "Wnt/ $\beta$-catenin signaling and disease," Cell, vol. 149, no. 6, pp. 1192-1205, 2012.

[122] B. T. MacDonald, K. Tamai, and X. He, "Wnt/ $\beta$-catenin signaling: components, mechanisms, and diseases," Developmental Cell, vol. 17, no. 1, pp. 9-26, 2009.

[123] M. S. Balda and K. Matter, "Epithelial cell adhesion and the regulation of gene expression," Trends in Cell Biology, vol. 13, no. 6, pp. 310-318, 2003.

[124] S. P. S. Monga, "Role and regulation of $\beta$-catenin signaling during physiological liver growth," Gene Expression, vol. 16, no. 2, pp. 51-62, 2014.

[125] S. P. Monga, " $\beta$-catenin signaling and roles in liver homeostasis, injury, and tumorigenesis," Gastroenterology, vol. 148, no. 7, pp. 1294-1310, 2015.

[126] U. Apte, M. D. Thompson, S. Cui, B. Liu, B. Cieply, and S. P. S. Monga, "Wnt $/ \beta$-catenin signaling mediates oval cell response in rodents," Hepatology, vol. 47, no. 1, pp. 288-295, 2008. 
[127] L. Boulter, O. Govaere, T. G. Bird et al., "Macrophage-derived Wnt opposes Notch signaling to specify hepatic progenitor cell fate in chronic liver disease," Nature Medicine, vol. 18, no. 4, pp. 572-579, 2012.

[128] M. Hu, M. Kurobe, Y. J. Jeong et al., "Wnt/ $\beta$-catenin signaling in murine hepatic transit amplifying progenitor cells," Gastroenterology, vol. 133, no. 5, pp. 1579-1591, 2007.

[129] S. Mokkapati, K. Niopek, L. Huang et al., " $\beta$-catenin activation in a novel liver progenitor cell type is sufficient to cause hepatocellular carcinoma and hepatoblastoma," Cancer Research, vol. 74, no. 16, pp. 4515-4525, 2014.

[130] J. Soeda, A. Mouralidarane, S. Ray et al., "The betaadrenoceptor agonist isoproterenol rescues acetaminopheninjured livers through increasing progenitor numbers by Wnt in mice," Hepatology, vol. 60, no. 3, pp. 1023-1034, 2014.

[131] W. Yang, H.-X. Yan, L. Chen et al., "Wnt/ $\beta$-catenin signaling contributes to activation of normal and tumorigenic liver progenitor cells," Cancer Research, vol. 68, no. 11, pp. 4287-4295, 2008.

[132] A. J. Schneider, A. M. Branam, and R. E. Peterson, "Intersection of AHR and Wnt signaling in development, health, and disease," International Journal of Molecular Sciences, vol. 15, no. 10, pp. 17852-17885, 2014.

[133] A. Braeuning, R. Sanna, J. Huelsken, and M. Schwarz, "Inducibility of drug-metabolizing enzymes by xenobiotics in mice with liver-specific knockout of ctnnbl," Drug Metabolism and Disposition, vol. 37, no. 5, pp. 1138-1145, 2009.

[134] D. R. Chesire, T. A. Dunn, C. M. Ewing, J. Luo, and W. B. Isaacs, "Identification of aryl hydrocarbon receptor as a putative Wnt/ $\beta$-catenin pathway target gene in prostate cancer cells," Cancer Research, vol. 64, no. 7, pp. 2523-2533, 2004.

[135] S. Benhamouche, T. Decaens, C. Godard et al., "Apc tumor suppressor gene is the 'zonation-keeper' of mouse liver," Developmental Cell, vol. 10, no. 6, pp. 759-770, 2006.

[136] A. Gougelet, C. Torre, P. Veber et al., “T-cell factor 4 and $\beta$ catenin chromatin occupancies pattern zonal liver metabolism in mice," Hepatology, vol. 59, no. 6, pp. 2344-2357, 2014.

[137] K. O. Lindros, T. Oinonen, I. Johansson, and M. IngelmanSundberg, "Selective centrilobular expression of the aryl hydrocarbon receptor in rat liver," Journal of Pharmacology and Experimental Therapeutics, vol. 280, no. 1, pp. 506-511, 1997.

[138] A. Braeuning, C. Köhle, A. Buchmann, and M. Schwarz, "Coordinate regulation of cytochrome P450 lal expression in mouse liver by the aryl hydrocarbon receptor and the $\beta$-catenin pathway," Toxicological Sciences, vol. 122, no. 1, pp. 16-25, 2011.

[139] S. Gerbal-Chaloin, A.-S. Dumé, P. Briolotti et al., “The WNT/bcatenin pathway is a transcriptional regulator of CYP2E1, CYP1A2, and aryl hydrocarbon receptor gene expression in primary human hepatocytes," Molecular Pharmacology, vol. 86, no. 6, pp. 624-634, 2014.

[140] S. Kasai, T. Ishigaki, R. Takumi, T. Kamimura, and H. Kikuchi, " $\beta$-Catenin signaling induces CYP1A1 expression by disrupting adherens junctions in Caco-2 human colon carcinoma cells," Biochimica et Biophysica Acta (BBA)-General Subjects, vol. 1830, no. 3, pp. 2509-2516, 2013.

[141] S. Vaas, L. Kreft, M. Schwarz, and A. Braeuning, "Cooperation of structurally different aryl hydrocarbon receptor agonists and $\beta$-catenin in the regulation of CYP1A expression," Toxicology, vol. 325, pp. e31-e41, 2014.

[142] Y. Zhang, X.-M. Li, F.-K. Zhang, and B.-E. Wang, "Activation of canonical Wnt signaling pathway promotes proliferation and self-renewal of rat hepatic oval cell line WB-F344 in vitro," World Journal of Gastroenterology, vol. 14, no. 43, pp. 66736680, 2008.

[143] K. Kawajiri, Y. Kobayashi, F. Ohtake et al., "Aryl hydrocarbon receptor suppresses intestinal carcinogenesis in ApcMin/+ mice with natural ligands," Proceedings of the National Academy of Sciences of the United States of America, vol. 106, no. 32, pp. 13481-13486, 2009.

[144] S. Angers and R. T. Moon, "Proximal events in Wnt signal transduction," Nature Reviews Molecular Cell Biology, vol. 10, no. 7, pp. 468-477, 2009.

[145] H. C. Bisgaard, P. Nagy, P. T. Ton, Z. Hu, and S. S. Thorgeirsson, "Modulation of keratin 14 and $\alpha$-fetoprotein expression during hepatic oval cell proliferation and liver regeneration," Journal of Cellular Physiology, vol. 159, no. 3, pp. 475-484, 1994.

[146] M. Golding, C. E. Sarraf, E.-N. Lalani et al., "Oval cell differentiation into hepatocytes in the acetylaminofluorene-treated regenerating rat liver," Hepatology, vol. 22, no. 4, pp. 1243-1253, 1995.

[147] A. M. Branam, N. M. Davis, R. W. Moore, A. J. Schneider, C. M. Vezina, and R. E. Peterson, "TCDD inhibition of canonical wnt signaling disrupts prostatic bud formation in mouse urogenital sinus," Toxicological Sciences, vol. 133, no. 1, pp. 42-53, 2013.

[148] H. Tsang, T.-Y. Cheung, S. P. Kodithuwakku et al., "2,3,7,8Tetrachlorodibenzo-p-dioxin (TCDD) suppresses spheroids attachment on endometrial epithelial cells through the downregulation of the Wnt-signaling pathway," Reproductive Toxicology, vol. 33, no. 1, pp. 60-66, 2012.

[149] G. Xu, Q. Zhou, C. Wan et al., “2,3,7,8-TCDD induces neurotoxicity and neuronal apoptosis in the rat brain cortex and $\mathrm{PC12}$ cell line through the down-regulation of the Wnt/ $\beta$-catenin signaling pathway," NeuroToxicology, vol. 37, pp. 63-73, 2013.

[150] S. Zhao, Y. Kanno, M. Nakayama, M. Makimura, S. Ohara, and Y. Inouye, "Activation of the aryl hydrocarbon receptor represses mammosphere formation in MCF-7 cells," Cancer Letters, vol. 317, no. 2, pp. 192-198, 2012.

[151] Q. Wang, H. Kurita, V. Carreira et al., "Ah receptor activation by dioxin disrupts activin, BMP, and WNT signals during the early differentiation of mouse embryonic stem cells and inhibits cardiomyocyte functions," Toxicological Sciences, vol. 149, no. 2, pp. 346-357, 2016.

[152] L. Attisano and J. L. Wrana, "Signal integration in TGF- $\beta$, WNT, and Hippo pathways," F1000Prime Reports, vol. 5, article17, 2013.

[153] X. Guo and X.-F. Wang, "Signaling cross-talk between TGF$\beta /$ BMP and other pathways," Cell Research, vol. 19, no. 1, pp. 7188, 2009.

[154] A. Sánchez and I. Fabregat, "Growth factor- and cytokinedriven pathways governing liver stemness and differentiation," World Journal of Gastroenterology, vol. 16, no. 41, pp. 5148-5161, 2010.

[155] T. G. Bird, S. Lorenzini, and S. J. Forbes, "Activation of stem cells in hepatic diseases," Cell and Tissue Research, vol. 331, no. 1, pp. 283-300, 2008.

[156] J. B. Clark, L. Rice, T. Sadiq et al., "Hepatic progenitor cell resistance to TGF- $\beta$ l's proliferative and apoptotic effects," Biochemical and Biophysical Research Communications, vol. 329, no. 1, pp. 337-344, 2005.

[157] Z.-Y. Ding, H.-F. Liang, G.-N. Jin et al., "Smad6 suppresses the growth and self-renewal of hepatic progenitor cells," Journal of Cellular Physiology, vol. 229, no. 5, pp. 651-660, 2014. 
[158] L. N. Nguyen, M. H. Furuya, L. A. Wolfraim et al., "Transforming growth factor-beta differentially regulates oval cell and hepatocyte proliferation," Hepatology, vol. 45, no. 1, pp. 31-41, 2007.

[159] H. Zaher, P. M. Fernandez-Salguero, J. Letterio et al., "The involvement of aryl hydrocarbon receptor in the activation of transforming growth factor- $\beta$ and apoptosis," Molecular Pharmacology, vol. 54, no. 2, pp. 313-321, 1998.

[160] A. Puga, A. Maier, and M. Medvedovic, "The transcriptional signature of dioxin in human hepatoma HepG2 cells," Biochemical Pharmacology, vol. 60, no. 8, pp. 1129-1142, 2000.

[161] C. Sahlberg, E. Peltonen, P.-L. Lukinmaa, and S. Alaluusua, "Dioxin alters gene expression in mouse embryonic tooth explants," Journal of Dental Research, vol. 86, no. 7, pp. 600-605, 2007.

[162] C. Rodgarkia-Dara, S. Vejda, N. Erlach et al., "The activin axis in liver biology and disease," Mutation Research-Reviews in Mutation Research, vol. 613, no. 2-3, pp. 123-137, 2006.

[163] L. Chen, W. Zhang, H.-F. Liang et al., "Activin A induces growth arrest through a SMAD-dependent pathway in hepatic progenitor cells," Cell Communication and Signaling, vol. 12, article 18, 2014.

[164] P. Yao, Y. Zhan, W. Xu et al., "Hepatocyte growth factor-induced proliferation of hepatic stem-like cells depends on activation of NF-kappaB," Journal of Hepatology, vol. 40, pp. 391-398, 2004.

[165] R. P. Evarts, Z. Hu, K. Fujio, E. R. Marsden, and S. S. Thorgeirsson, "Activation of hepatic stem cell compartment in the rat: role of transforming growth factor alpha, hepatocyte growth factor, and acidic fibroblast growth factor in early proliferation," Cell Growth \& Differentiation, vol. 4, no. 7, pp. 555-561, 1993.

[166] R. P. Evarts, H. Nakatsukasa, E. R. Marsden, Z. Hu, and S. S. Thorgeirsson, "Expression of transforming growth factoralpha in regenerating liver and during hepatic differentiation," Molecular Carcinogenesis, vol. 5, no. 1, pp. 25-31, 1992.

[167] B. Du, N. K. Altorki, L. Kopelovich, K. Subbaramaiah, and A. J. Dannenberg, "Tobacco smoke stimulates the transcription of amphiregulin in human oral epithelial cells: evidence of a cyclic AMP-responsive element binding protein-dependent mechanism," Cancer Research, vol. 65, no. 13, pp. 5982-5988, 2005.

[168] S. S. H. Choi, M. A. Miller, and P. A. Harper, "In utero exposure to 2,3,7,8-tetrachlorodibenzo-p-dioxin induces amphiregulin gene expression in the developing mouse ureter," Toxicological Sciences, vol. 94, no. 1, pp. 163-174, 2006.

[169] S. Kiso, S. Kawata, S. Tamura et al., "Liver regeneration in heparin-binding EGF-like growth factor transgenic mice after partial hepatectomy," Gastroenterology, vol. 124, no. 3, pp. 701707, 2003.

[170] C. Mitchell, M. Nivison, L. F. Jackson et al., "Heparin-binding epidermal growth factor-like growth factor links hepatocyte priming with cell cycle progression during liver regeneration," The Journal of Biological Chemistry, vol. 280, no. 4, pp. 2562$2568,2005$.

[171] E. Miyoshi, S. Higashiyama, T. Nakagawa et al., "High expression of heparin-binding EGF-like growth factor in rat hepatocarcinogenesis," International Journal of Cancer, vol. 68, no. 2, pp. 215-218, 1996.

[172] J. W. Davis II, F. T. Lauer, A. D. Burdick, L. G. Hudson, and S. W. Burchiel, "Prevention of apoptosis by 2,3,7,8tetrachlorodibenzo-p-dioxin (TCDD) in the MCF-10A cell line: correlation with increased transforming growth factor $\alpha$ production," Cancer Research, vol. 61, no. 8, pp. 3314-3320, 2001.
[173] R. D. Patel, D. J. Kim, J. M. Peters, and G. H. Perdew, “The aryl hydrocarbon receptor directly regulates expression of the potent mitogen epiregulin," Toxicological Sciences, vol. 89, no. 1, pp. 7582, 2006.

[174] J.-S. Mo, H. W. Park, and K.-L. Guan, “The Hippo signaling pathway in stem cell biology and cancer," EMBO Reports, vol. 15, no. 6, pp. 642-656, 2014.

[175] F.-X. Yu and K.-L. Guan, "The Hippo pathway: regulators and regulations," Genes and Development, vol. 27, no. 4, pp. 355-371, 2013.

[176] D. Lai, K. C. Ho, Y. Hao, and X. Yang, "Taxol resistance in breast cancer cells is mediated by the hippo pathway component TAZ and its downstream transcriptional targets Cyr61 and CTGF," Cancer Research, vol. 71, no. 7, pp. 2728-2738, 2011.

[177] B. Zhao, X. Ye, J. Yu et al., "TEAD mediates YAP-dependent gene induction and growth control," Genes and Development, vol. 22, no. 14, pp. 1962-1971, 2008.

[178] S. Piccolo, S. Dupont, and M. Cordenonsi, "The biology of YAP/TAZ: hippo signaling and beyond," Physiological reviews, vol. 94, no. 4, pp. 1287-1312, 2014.

[179] B. Zhao, X. Wei, W. Li et al., "Inactivation of YAP oncoprotein by the Hippo pathway is involved in cell contact inhibition and tissue growth control," Genes \& Development, vol. 21, pp. 27472761, 2007.

[180] F. X. Yu, Z. Meng, S. W. Plouffe, and K. Guan, "Hippo pathway regulation of gastrointestinal tissues," Annual Review of Physiology, vol. 77, no. 1, pp. 201-227, 2015.

[181] D. Yimlamai, C. Christodoulou, G. G. Galli et al., "Hippo pathway activity influences liver cell fate," Cell, vol. 157, no. 6, pp. 1324-1338, 2014.

[182] N. Zhang, H. Bai, K. K. David et al., "The Merlin/NF2 tumor suppressor functions through the YAP oncoprotein to regulate tissue homeostasis in mammals," Developmental Cell, vol. 19, no. 1, pp. 27-38, 2010.

[183] M. A. Kowalik, C. Saliba, M. Pibiri et al., "Yes-associated protein regulation of adaptive liver enlargement and hepatocellular carcinoma development in mice," Hepatology, vol. 53, no. 6, pp. 2086-2096, 2011.

[184] J. Fitamant, F. Kottakis, S. Benhamouche et al., "YAP inhibition restores hepatocyte differentiation in advanced HCC, leading to tumor regression," Cell Reports, vol. 10, no. 10, pp. 1692-1707, 2015.

[185] H. Hayashi, T. Higashi, N. Yokoyama et al., "An imbalance in TAZ and YAP expression in hepatocellular carcinoma confers cancer stem cell-like behaviors contributing to disease progression," Cancer Research, vol. 75, no. 22, pp. 4985-4997, 2015.

[186] H. Xiao, N. Jiang, B. Zhou, Q. Liu, and C. Du, “TAZ regulates cell proliferation and epithelial-mesenchymal transition of human hepatocellular carcinoma," Cancer Science, vol. 106, no. 2, pp. 151-159, 2015.

[187] H. Li, A. Wolfe, S. Septer et al., "Deregulation of Hippo kinase signalling in human hepatic malignancies," Liver International, vol. 32, no. 1, pp. 38-47, 2012.

[188] A.-T. Yang, P. Wang, X.-F. Tong et al., "Connective tissue growth factor induces hepatic progenitor cells to differentiate into hepatocytes," International Journal of Molecular Medicine, vol. 32, no. 1, pp. 35-42, 2013.

[189] S. Kim, E. Dere, L. D. Burgoon, C.-C. Chang, and T. R. Zacharewski, "Comparative analysis of AhR-mediated TCDDelicited gene expression in human liver adult stem cells," Toxicological Sciences, vol. 112, no. 1, pp. 229-244, 2009. 
[190] K. Pande, S. M. Moran, and C. A. Bradfield, "Aspects of dioxin toxicity are mediated by interleukin 1-like cytokines," Molecular Pharmacology, vol. 67, no. 5, pp. 1393-1398, 2005.

[191] B. Knight, V. B. Matthews, B. Akhurst et al., "Liver inflammation and cytokine production, but not acute phase protein synthesis, accompany the adult liver progenitor (oval) cell response to chronic liver injury," Immunology and Cell Biology, vol. 83, no. 4, pp. 364-374, 2005.

[192] B. Knight, G. C. T. Yeoh, K. L. Husk et al., "Impaired preneoplastic changes and liver tumor formation in tumor necrosis factor receptor type 1 knockout mice," Journal of Experimental Medicine, vol. 192, no. 12, pp. 1809-1818, 2000.

[193] L. Umannová, J. Zatloukalová, M. Machala et al., “Tumor necrosis factor- $\alpha$ modulates effects of aryl hydrocarbon receptor ligands on cell proliferation and expression of cytochrome P450 enzymes in rat liver 'stem-like' cells," Toxicological Sciences, vol. 99, no. 1, pp. 79-89, 2007.

[194] M. Kabátková, J. Svobodová, K. Pěnčíková et al., "Interactive effects of inflammatory cytokine and abundant low-molecularweight PAHs on inhibition of gap junctional intercellular communication, disruption of cell proliferation control, and the AhR-dependent transcription," Toxicology Letters, vol. 232, no. 1, pp. 113-121, 2015.

[195] L. Šmerdová, J. Svobodová, M. Kabátková et al., “Upregulation of CYP1B1 expression by inflammatory cytokines is mediated by the p38 MAP kinase signal transduction pathway," Carcinogenesis, vol. 35, no. 11, pp. 2534-2543, 2014.

[196] L. Umannová, M. Machala, J. Topinka et al., "Tumor necrosis factor- $\alpha$ potentiates genotoxic effects of benzo[a]pyrene in rat liver epithelial cells through upregulation of cytochrome P450 1B1 expression," Mutation Research/Fundamental and Molecular Mechanisms of Mutagenesis, vol. 640, no. 1-2, pp. 162-169, 2008. 

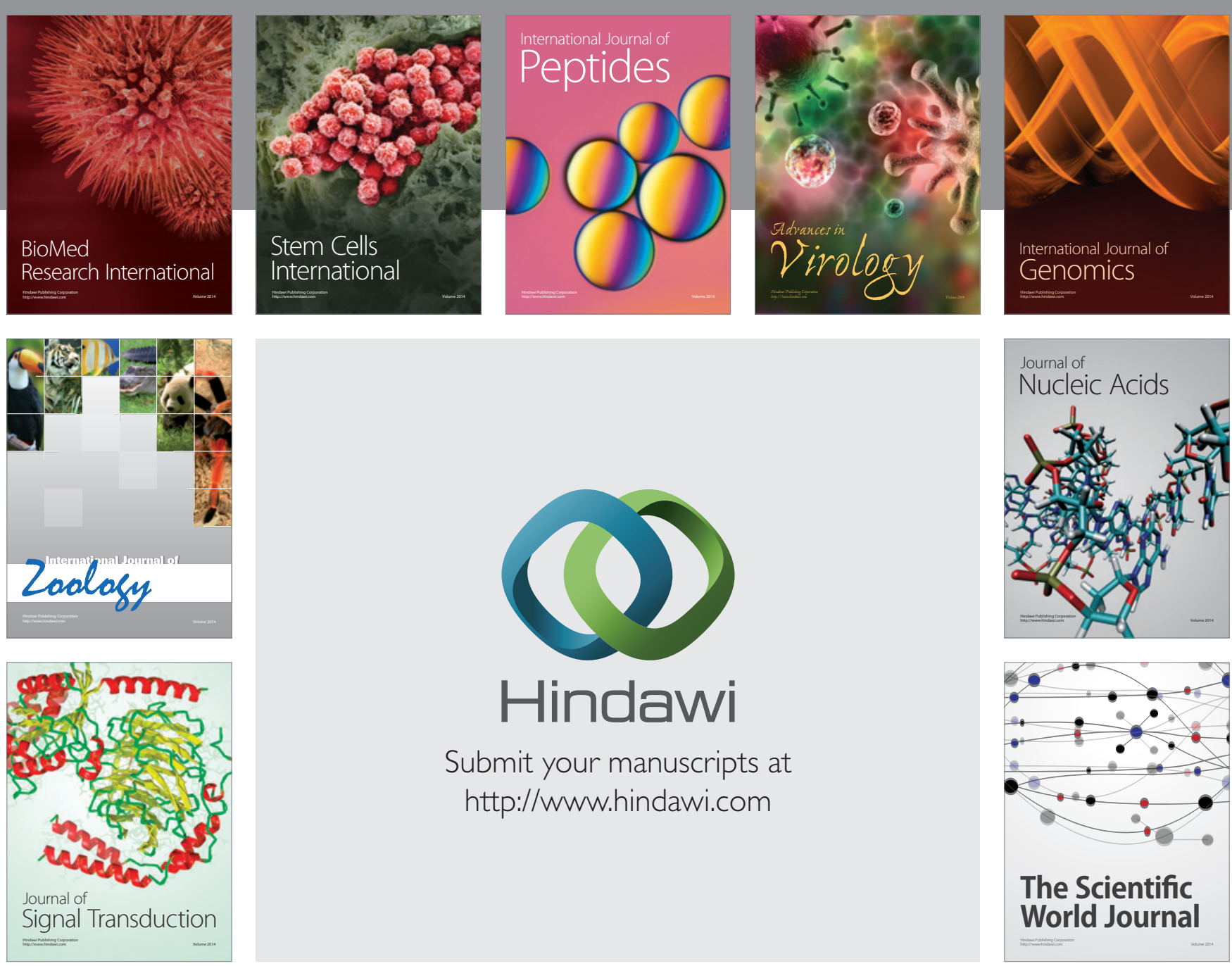

Submit your manuscripts at

http://www.hindawi.com
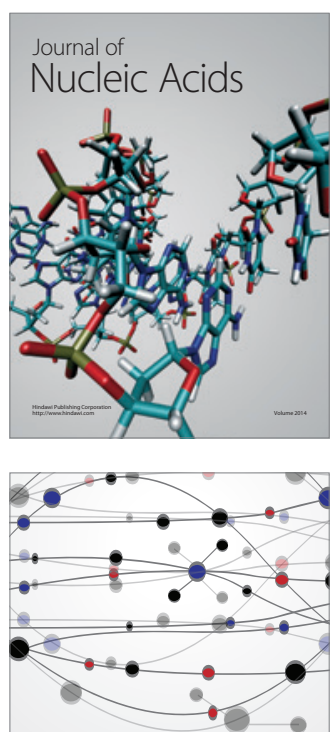

The Scientific World Journal
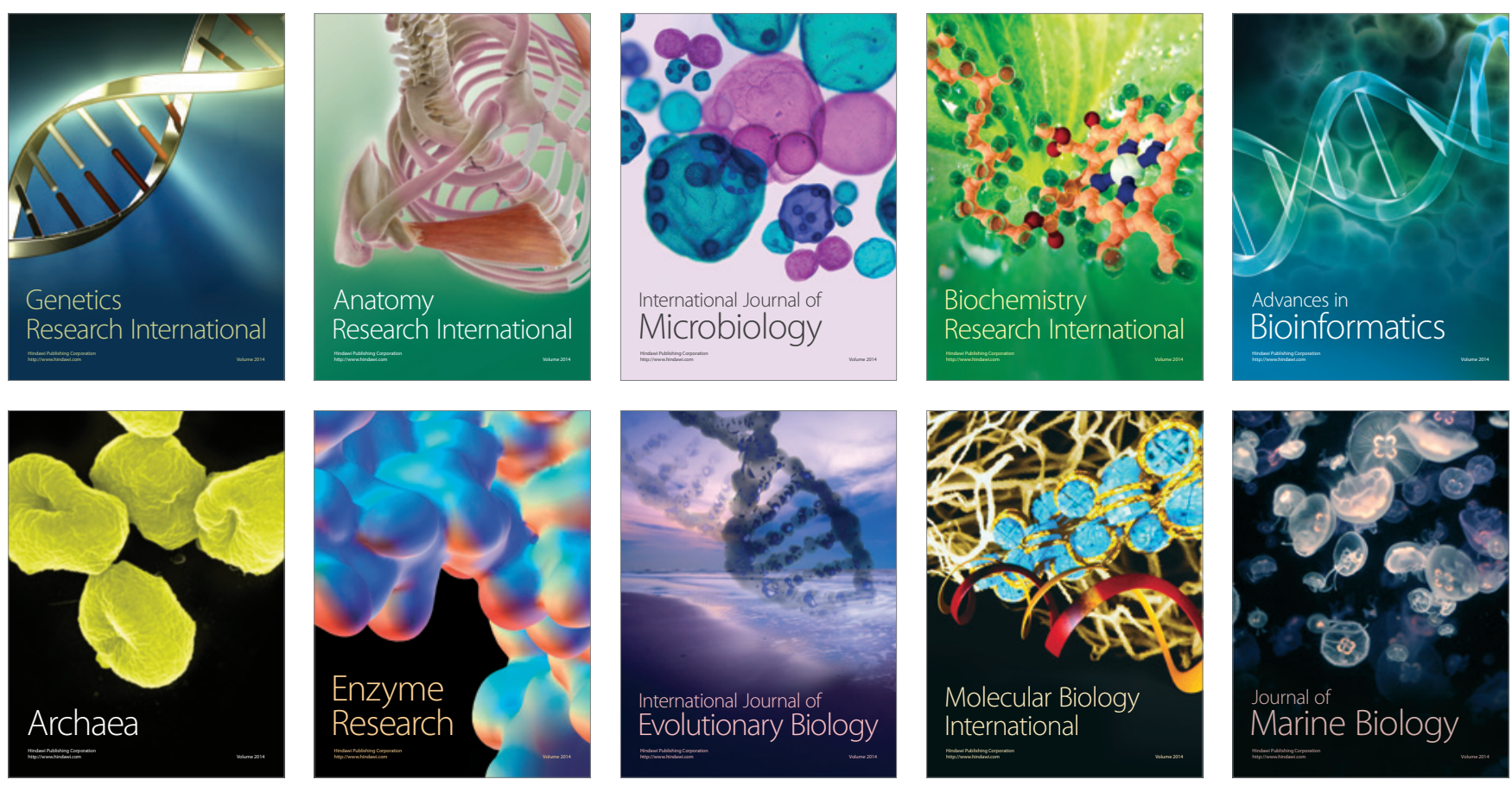